\title{
THE SPIRIT OF ENTREPRENEURSHIP IN BUSINESS STUDENTS, NON- BUSINESS STUDENTS, AND SMALL AND MEDIUM ENTREPRENEUR
}

\author{
Niluh Made Dian Novita Handayani Narsa ${ }^{1}$ I Made Narsa ${ }^{2}$, \\ Niluh Putu Dian Rosalina Handayani Narsa ${ }^{3 *}$ \\ ${ }^{1,2,3}$ Department of Accounting, Faculty of Economics and Business, Airlangga University \\ Airlangga Street 4-6, Surabaya 60115, Indonesia \\ *Corresponding author; Email: ${ }^{3}$ niluh.narsa@ feb.unair.ac.id
}

\begin{abstract}
There is debate as to whether entrepreneurs are born or can be created through education. Many business schools were established to produce entrepreneurs, but the fact is that many succesful entrepreneurs are not graduates of business schools. This study aims to examine empirically the entrepreneurial spirit of three different sample groups students who undertook a business course (accounting students), non-business students (engineering students), businessmen who are already involved in business activities (entrepreneurs). This study used a survey method. Data were analyzed using ANOVA. The total sample of this research were 254 respondents. The result showed that there was no empirical evidence regarding the entrepreneurial differences in the three groups. It was concluded that entrepreneurial skills are either there or not from birth. Business courses are not (or not yet) capable of triggering the entrepreneurial skills in a person.
\end{abstract}

Keywords: Entrepreneurial, entrepreneur, business student, non-business student.

\section{Introduction}

When Indonesia experiences an economic downturn, and the number of unemployed increase, it is necessary to have entrepreneurs who can create new jobs (Bohušová \& Blašková, 2012). The government will not be able to assist with all aspects of development, therefore, people who have an entrepreneurial spirit become very important because of their development potential, and thus should be encouraged in their entrepreneurial activities.

A person who is an entrepreneur can be influenced by many factors, such as: entrepreneurial spirit, entrepreneurship education, family, association, environment, and so forth. Indarti and Kristiansen (2003) found that entrepreneurial desire in Norway is influenced by personal and environmental factors. Setyorini and Sunaryo (2004) found a positive influence of personal factors and environmental factors collectively towards the desire for entrepreneurship.

Further research into entrepreneurship was done by Ciptono (1994) who examined the trend of entrepreneurial traits of Indonesian students studying in America. The study revealed that the entrepreneurial tendency of Indonesian students (70 people as the sample) leads to sensational perception, and that temperament has no effect on entrepreneurial tendencies. This study has limitations, because it used a sample of all the lecturers who had a business education background. Therefore, Ciptono (1994) suggests the need to re-visit his research by determining more relevant and diverse population targets.
Carland, Carland, and Higgs (1993) conducted a study of 147 US business students and found that temperament was very significantly associated with the entrepreneurial index. This means entrepreneurship tends to be the potential possessed by certain people, which will be more developed if they interact with their environment. This is in line with what was put forward by Alma (2005), that the entrepreneurial spirit is born or is a trait.

There are two theories about how entrepreneurs develop, namely the "supply" and "demand" theories (Burch, 1986). The theory of supply, explains that entrepreneurs are born, not created - certain people have personality traits that make them successful entrepreneurs. A lot of evidence show that a person who does not get a business education, whether formal or informal (low school level), may still succeed in becoming an entrepreneur, perhaps because they have an entrepreneurial spirit. For a more indepth discussion, see: Henry Ford, Thomas Edison, Phillips, Krupp, Mitsui, Sciciro Honda, Liem Sio Liong, Pardede, Bahrudin, (Alma, 2005).

Around an academic environment, the theory of demand is more common than the supply theory. Demand theory explains that one can be an entrepreneur because he/she has the opportunity and is in a favorable position to take the opportunity. In addition, it is also caused by environmental and educational factors. The essence of demand theory explains that entrepreneurship can be taught. Hisrich and Peters (1995) stated that "entrepreneurs are not born, they develop". That is why many educational institutions 
teach entrepreneurship education and this has become one of the reasons why entrepreneurship is incorporated in curriculum as a subject.

The contradictions of the theories, and the magnitude of the hope for the role of these entrepreneurs, led many researchers to conduct research to try to clarify the entrepreneurial spirit, including examining the factors that allegedly influence the tendency of entrepreneurship, for example, (Alexandrova, 2004; Carland, et al., 1993; Ciptono, 1994; Indarti \& Kristiansen, 2003; Lumpkin \& Dess, 1996; Mahrinasari, 2003; Mueller \& Thomas, 2000; Wiratmo, 1996) and so forth.

There is an emerging research gap, all the studies mentioned above only used business students as their subjects (Carland et al., 1993; Ciptono, 1994; Mueller \& Thomas, 2000) or business travelers (Alexandrova, 2004; Lumpkin \& Dess, 1996). They acknowledge that their research has a weakness because the samples only used business students and they suggest that future research be conducted on a variety of samples. Thus this research tries to use a sample which not only comes from one group, hence our use of business students, non-business students, and business professionals being questioned by entrepreneurial students. Thre reason of why all of the respondents is an Indonesian citizen is because Indonesia is a collectivism country, which as found by Zeffane (2014), the impact of collectivism on entrepreneurial potential is significant.

Based on different views of the entrepreneurial spirit and the results of empirical research, the problem of the research is whether the entrepreneurial spirit is attached as a talent or trait from birth, or does an entrepreneurial spirit arise when acquiring a business education. Secondly, is there a systematic difference in the entrepreneurship shown by business students, non-business students, and entrepreneurs from small and medium enterprises.

This study is an extension of Ciptono's research (1994) by adding sample variations, with the aim of obtaining empirical data of the entrepreneurship spirit trends in three different sample groups, ie students who obtain a business education, in this case they are students majoring in accounting. The second group are non-business students, ie students who do not have business education, in this case they are students from a technical faculty, and third group are entrepreneurs who already carry out business activities, which in this case is surrogated with students who have been doing business (students of Ciputra University).

The results of the research may make a contribution, in the form of inputs into the framework of curriculum arrangement and the pattern of implemen- tation of the learning process for entrepreneurship subjects, if the results of this study find that the entrepreneurial spirit is attached to a person as a talent (trait) since birth. If so, then they should be urged to obtain a business education so they can obtain optimal results. Thus, it is expected that there will be improvements in the business admission system, oriented toward becoming an entrepreneur.

This paper further describes the theoretical basis and the development of the hypotheses for this research, followed by an explanation of the research methods, results and research discussions. Finally, the conclusions and limitations will close the whole paper.

In much of the literature, the terms entrepreneur, entrepreneurial, and entrepreneurship are used interchangeably; either for the same purpose or with a different interpretation. To clarify, in the context of this study, these terms are translated as: Entrepreneurs are entrepreneurs; entrepreneurial is an entrepreneurial spirit; and entrepreneurship is a dynamic process that combines behavior with time dimensions or entrepreneurship.

The word entrepreneur was first used in 1723 by Savary (Alma, 2005) and meant people who buy goods at a fixed price, and later sell them at a different price, although the person does not yet know what that selling price will be. The uncertain word in that sense implies risk. Thus entrepreneurs are people who dare to take and bear a risk.

Various studies have revealed the characteristics of an entrepreneur. As revealed by Scarborough and Zimmerer in Suryana (2006), there are eight characteristics of entrepreneurship, namely: (1) Desire for responsibility: possesses a sense of responsibility for the business undertaken. Self-awareness will be part of someone who has this responsibility. (2) Preference for moderate risk: entrepreneurs prefer moderate risk. In a sense he does not choose low-risk or one too high. (3) Confidence in their ability in success: possesses confidence that he/she will succeed. (4) Desire for immediate feedback: always requires quick feedback. (5) High level of energy: a hard worker and has the passion to fulfill their desires. (6) Future orientation: possesses perspective and far-sightedness. (7) Skilled at organizing: having the skills to organize the resources to create added value. (8) Value of achievement over money: more respect for achievement than money.

An entrepreneur is an inventor, they will not buy a business. To become an entrepreneur, the success of a discovery and the effort spent on it is measured by its growth. Although everyone can become an entrepreneur, in reality it is not so. According to Mitchel- 
more and Rowley (2010), it is related to entrepreneurial competence and the business's appearance. From a number of studies, entrepreneurial competence is determined by a number of factors, including the person's background and experience (such as trading experience, inventory history, production and marketing experience, entrepreneurship status and contacts with other companies). Secondly, as revealed by Masu and Goswani (1999) there are socioeconomic factors, such as the person's educational attainment, previous business experience, including the family's business background and how long they have operated in the business world, financial recognition, and familiar financial sources of information. Mitchelmore and Rowley (2010) suggested that unplanned action, the absence of financial evaluations, inappropriate delegation, functional inadequacy to support an unsustainable business and management and not understanding marketing also determine entrepreneurship. Finally, intellectual and social capabilities, and the person's managerial skills are determinants of their success as an entrepreneur.

Barreira (2010) added to the characteristics of an entrepreneur. According to him, besides being an inventor, an entrepreneur also has the courage to take risks in moderation, as well as being tolerant of ambiguity and uncertainty. Table 1 summarizes the characteristics attached to an entrepreneur by the behaviorists.

While Lumpkin and Dess (1996) clearly used the term entrepreneurial in his research and the entreprenurial dimensions, according to Lumpkin and Dess (1996), consisting of: autonomy, innovativeness, risk taking, proactiveness and competitive aggressiveness. People who have these characteristics are entrepreneurs. While Carland et al. (1993) argued that entrepreneurial dimensions are a function of four elements, firstly is personality, secondly is innovation, thridly is risk taking propensity, and then lastly is strategic posture.

Drucker (1994) defined entrepreneurship as the ability to create something new and different. Similarly, Schumpeter in Idrus (1999) stated that entrepreneurship is the driving of emergence of economic growth, and is able to formulate new economic combinations through: (1) new product development; (2) development of new material resources; (3) accumulation of capital resources; (4) introducing new products and new production functions and (5) organizing or developing new industries. An important essence of the definition of entrepreneurship is the incremental wealth of the value creation process, as a result of the process. It is also parallel to the need for achievement.
Table 1

Characteristics that Exist in an Entrepreneur

\begin{tabular}{ll}
\hline Characteristic & Characteristic \\
\hline Innovator & Self-conscious \\
Leader & Confident \\
Moderate risk taker & $\begin{array}{l}\text { Tolerant of ambiguity and } \\
\text { uncertainty }\end{array}$ \\
& Engaged in the long run \\
Creator & Initiative \\
Energetic & Learner \\
Original & Using resources \\
Persistent & Have sensitivity \\
Optimistic & Aggressive \\
Orientation on results & Tend to believe in others \\
Flexible & Money as a measure of \\
Able to search for & appearance \\
resources & \\
Need for achievement &
\end{tabular}

Source: Barreira (2010)

Thus, if the three concepts of entrepreneur, entrepreneurial and entrepreneurship are combined they will form a very comprehensive and clear definition. Entrepreneurship is not identified by anything formal, or a title, but is based on its success in practice and innovation. Many notions of entrepreneurship are stated differently, but all basically have the same intent. Pekerti (1992), said entrepreneurship is a response to business opportunities that are revealed in a set of actions, and produce results in the form of organizational organizations that are institutionalized, productive, and innovative. Furthermore, Anugrah Pekerti reveals that successful entrepreneurs need not only be supported by talent, but also the level of education that they can obtain, and they are closely related to the business environment.

Successful entrepreneurs must have an entrepreneurial or talented spirit, while the environment and their education moderate the entrepreneurial spirit's level to help them become a successful entrepreneur. Entrepreneurship is the creation of innovative organizational (organizational networking) organizations, in order to gain profits or growth under conditions that bear uncertainty and also risk (Dollinger, 1995). Graphically, they can be illustrated, as shown in Picture 1.

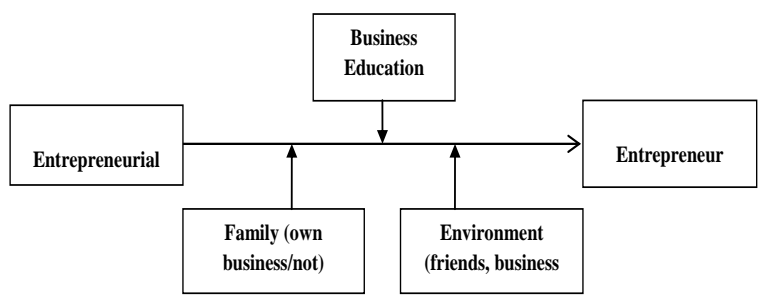

Picture 1. The relationship of various drivers to become an entrepreneur 
In Picture 1 it appears that, to be an entrepreneur, one must have a talent or entrepreneurial spirit. Environmental factors merely moderate the entrepreneurial spirit. In general, an entrepreneur has characteristics such as a great need to meet his/her goals, the desire to take risks, confidence, and have a strong business will (Longenecker, Moore, \& Petty, 2000).

Kartasasmita (1994) said that some entrepreneurial entrepreneurship factors are seeing an opportunity and innovative search methods, persistence, adherence to contracts, the demand for quality and efficiency, risk-taking, goal setting, information searches, systematic planning and monitoring, persuasion and the creation of networks, confidence, innovation, and knowledge. Both the characteristics and the quality of the entrepreneurial spirit, are seen as being closely related to the educational, personal and environmental factors. It can be said that the three factors are basically the factors that can moderate the entrepreneurial spirit in someone, by doing a dynamic process to create value (entrepreneurship).

Wiratmo (1996) defined entrepreneurship as the creation process of something of different value by using effort and time, as required, while taking into account the some types of risks (which are: psychological, social, and also financial) that accompany this, and finally in return will receive monetary rewards and personal satisfaction. For that, the desire of entrepreneurship is defined as an impulse from within the individual, that motivates behavior toward the achievement of goals by way of the creation of something of different value. A study by Indarti and Kristiansen (2003) found that entrepreneurial desire in Norway was influenced by personal and environmental factors. The personal factors consist of: achievement motivation (need for achievement), locus of control, and belief in self-efficacy (self efficacy). While the environmental factors consist of: access to capital, access to information, and social relations (social network). This research is supported by the research of Setyorini and Sunaryo (2004), which stated that there is a positive influence of both personal factors and environmental factors towards the desire for entrepreneurship. In this study, it was also stated that the personal factors' influence was more dominant than that of the environmental factors on the desire for entrepreneurship. The dominance of personal factors over the environmental factors makes

It is necessary to distinguish between entrepreneurial spirit and entrepreneurial knowledge. The definition of entrepreneurship that has been proposed, in principle includes two aspects, namely entrepreneurial spirit and entrepreneurial knowledge. Entrepreneurial spirit includes talent, and being born with the relevant trait; while knowledge about entrepreneurship is obtained through education, both formal and non-formal, the interaction with the environment and also the influence of the family environment (Alma, 2005; Burch, 1986; Dollinger, 1995; Hisrich \& Peters, 1995; Longenecker et al., 2000; Pakerti, 1992; Wiratmo, 1996).

Thus the hypothesis of this study is that theoretically there is a systematic difference in the entrepreneurial spirit between people who possess a business education and those who do not possess a business education, and the people who are involved in business activities. Tests of this concept will be able to explain that if someone, who does not possess a business education, turns out to have a high entrepreneurial index this will mean their entrepreneurial ability is not because of their education, and vice versa. Also this study will describe the characteristics of entrepreneurs who are currently running business activities, in relation to the entrepreneurial spirit.

\section{Research Method}

This research is designed as an empirical research employing a survey method. Measurement of the entrepreneurial spirit is by using the Carland entrepreneurship index, developed in 1992 (Carland et al., 1993).

As an extension of the research conducted by Ciptono (1994), this study adds to the variety of samples, ie business students and non-businesses and entrepreneurs involved with small and medium enterprises. There were 85 respondents in each sample of the three groups, thus the total number of respondents for this research were 255. The sampling location for business students was taken from the students of the Faculty of Economics and Business, Airlangga University, majoring in Accounting, the sample of nonbusiness students was taken from the Faculty of Science and Technology, Airlangga University, and lastly the small and medium business entrepreneurs were taken from Ciputra University, which is a university of entrepreneurship, where all students are from SMEs or are entrepreneurs.

The instrument used in this study is the Carland entrepreneurship index. Carland et al. (1993) described the spirit of entrepreneurship as a construct that can solve differences in the entrepreneurial behavior of various individuals. The study by Carland et al. (1993), conducted over the previous decade, has been successful in devising an instrument for measuring the entrepreneurial spirit, hereinafter referred to as the Carland entrepreneurship index. There are four elements that determine one's entrepreneurial spirit, and 
those four are elements of the Carland Entrepreneurship Index (CEI) instrument, which are the preference for innovation, risk-taking propensity, strategic posture (also called the need for achievement), and the last is elements of cognitive style. This instrument consists of 33 question items that do not require any special skills to answer, and it takes only a few minutes to complete (Doyle, Fisher, \& Young, 2002). Each question item consists of two statements and the responder must choose one of these statements. One statement is worth one and another statement is zero. Thus, the scores from the CEI will vary from zero to 33. Scores close to zero indicate a low entrepreneurial drive, whereas scores close to 33 indicate a high entrepreneurial drive.

Before the data is analyzed more deeply, to ensure that the data collected are feasible for further analysis, they will be tested on their validity and reliability by using Cronbach's alpha and correlation tests. Data were presented using descriptive statistics to illustrate the characteristics of the subject and to determine the frequency and proportion of the data, the data's centering tendency, and its dispersion. To test whether there was a systematic difference between the entrepreneurship drive among business students, non-business students and small and medium entrepreneurs, an Analysis of Variance (ANOVA) test will be used.

\section{Research Result and Discussion}

This study used three groups of respondents. The first group comprised of business students, the second group of non-business students, and the third group of entrepreneurs. Here is a brief explanation of the demographics of the three groups.

A total of 86 of the business students , (43.5\%) were male and the remaining $48(56.5 \%)$ were female. From this gender composition it appears that there was a suitable balance between men and women. The reason why we not continuing the analysis based on gender is because as found by Mitchelmore and Rowley (2010) and Zeffane (2014), actualy the entrepreneurial spirit is not explained by gender differences.

Judging from their age, it appears that the majority of students were senior students. Their ages ranged from 17 to 22 years, of which $27.1 \%$ of students were under 20 years of age, and the remaining $78.9 \%$ were above 20 . This age indicates that they were in 6th semester and above.

Table 3 presents a characteristics description of the second group of respondents, ie the group of nonbusiness students. Twenty-five of the students
(29.4\%) were male and the remaining 60 (70.6\%) were female. Their ages ranged from 18 to 23 years old, with 32 students aged 18 to 20 years (37.6\%), and the remaining 52 students aged 21 to 23 years old $(62.4 \%)$.

The third group is the group of business actors. The number of respondents from this group who participated were 84 students. Of these, 57 students (67.8\%) were male and the remaining 27 students (32.2\%) were female. Their ages ranged from 19 to 22 years old, of which 43 students were 19 to 20 years old (51.2\%), and the remaining 41 students were 21 to 22 years old (48.8\%). The demographic data for the SMEs respondents' group is presented in more detail in Table 4.

From Table 4 it appears that the business field they perform as business actors. Thirty-five respondents $(41.7 \%)$ work in the food and beverage sector. Sixteen respondents (19.1\%) are employed in fashion and clothing businesses. Then 12 respondents (14.3\%) work in service industries. Eight respondents $(9.5 \%)$ are in the manufacturing field, while seven respondents $(8.3 \%)$ work in other fields. The remaining six respondents (7.1\%) are in the field of information and technology.

The turnover per month that they get as SME owners/workers ranged from one million rupiah to more than 50 million rupiah, with the maximum being 70 million rupiah. The details are as follows, a total of 49 respondents $(58.3 \%)$ have a turnover per month amounting to between one to less than five million rupiah. Then 24 respondents $(28.6 \%)$ have a turnover per month of five million rupiah to less than ten million rupiah. Then four respondents $(4.7 \%)$ have a monthly turnover between ten million rupiah and fifty million rupiah. Finally, there are only three respondents (3.6\%) who earn over fifty million rupiah per month.

\section{Descriptive Statistics Analysis}

Scores from the Carland Entrepreneurship Index (CEI), ranged from zero to 33, the higher the score the greater the entrepreneurship spirit. The following will explain the distribution of CEI scores from the three groups of respondents in this study.

As shown in Table 5 Panel A, the average CEI score for the group of business students is 17.72. There were 21 students $(24.7 \%)$ who scored in the range of 10-15. The majority of students $(51=60 \%)$ scored in the range of 16-20. The remaining 13 students (15.3\%) got a score between 21-25.

Based on Table 2 Panel B, the average CEI score for the group of non-business students is 17.35. 
Table 2

Descriptive Statistics of CEI Scores

Panel A: Busines Student Group

\begin{tabular}{|c|c|c|}
\hline Score & Frequency & Percentage \\
\hline $10-15$ & 21 & $24.7 \%$ \\
\hline $16-20$ & 51 & $60 \%$ \\
\hline $21-25$ & 13 & $15.3 \%$ \\
\hline Mean: 17.72 & & Minimum: 10 \\
\hline Median: 17 & & Maximum 25 \\
\hline \multicolumn{3}{|l|}{ Panel B: Non-Business Student Group } \\
\hline $10-15$ & 17 & $20 \%$ \\
\hline $16-20$ & 58 & $68.2 \%$ \\
\hline $21-23$ & 10 & $11.8 \%$ \\
\hline Mean: 17.35 & & Minimum: 10 \\
\hline Median: 17 & & Maximum: 23 \\
\hline \multicolumn{3}{|l|}{ Panel C: SME Business Group } \\
\hline $9-15$ & 24 & $28.5 \%$ \\
\hline $16-20$ & 46 & $54.7 \%$ \\
\hline $21-24$ & 14 & $16.8 \%$ \\
\hline Mean: 17.23 & & Minimum: 9 \\
\hline Median: 17 & & Maximum: 24 \\
\hline
\end{tabular}

Unlike the group of business students, the maximum score obtained by this group is 23 . There were 17 students $(20 \%)$ who scored in the range of $10-15$. As with the group of business students, most of the respondents in this group $(58=68.2 \%)$ had scores in the range of 16-20. The other 10 students scored $21-$ $23(11.8 \%)$.

Finally, for the group of business actors, Table 5 Panel $\mathrm{C}$ shows that the average CEI score for this group is $17.23 \%$. Unlike the previous two groups, the minimum score of this group was nine and the maximum 24 . There were 24 students $(28.5 \%)$ who scored 9-15. Then 46 students $(54.7 \%)$ had a score between 16-20, while 14 students (16.8\%) scored between 21-24.

There are several important things that can be inferred based on the descriptive statistics of each group. First, the average CEI scores from the three groups were equal to 17 , while the highest average score was obtained by the business students group (17.72), then the non-business students (17.35), and lastly the SME owners/workers (17.23). Then the minimum score of the three groups was 10 , by the group of business and non-business students, and only nine by the SME group; while the maximum scores were 25 for the group of business students, 24 for the SME business group, and 23 for the group of nonbusiness students.

Furthermore, it can be seen that the majority of the scores of the three groups are in the range from $16-20,68.2 \%$ of the group of non-business students achieved this, $60 \%$ of the group of business students, and $54.7 \%$ of the SME business group. The last important thing is, in the range of high scores between
21-25, the highest percentage of students who scored this were in the business group $(16.8 \%)$ followed by the group of business students $(15.3 \%)$ and last was the group of non-business students $(11.8 \%)$.

\section{Hypothesis Testing}

The purpose of this study is to examine whether there is a difference of the spirit of entrepreneurship among business students, non-business and business actors which is in here is SME owners or workers. Because there are three groups that will be compared, we used the test of Analysis of Variance (ANOVA). Here are the ANOVA test results.

By looking at the ANOVA test result above, it is known that the significance value of 0.531 is greater than the $5 \%$ confidence level $[p=0.635>0.05]$. Thus, the hypothesis proposed in this study is rejected, which means that there is no systematic difference in entrepreneurship between business students, nonbusiness students and business owners/ workers. Further exposure will be explained in the next section, which is the discussion.

\section{Discussion}

This research has two problem formulas, the first is whether entrepreneurial is a talent or a trait that humans are born with, or is an entrepreneurial spirit obtained from a business education. Secondly, there is a systematic difference between the entrepreneurship among business students, non-business students, and business people. The answers to both of these problems will be explained in the following section. 
Table 3

Descriptive Statistics of Entrepreneurial Score

\begin{tabular}{lccccc}
\hline \multicolumn{1}{c}{ Description } & $\boldsymbol{N}$ & Mean & Range & Std. Deviation & Std. E \\
\hline Business Student & 85 & 17.72 & $10-25$ & 3.018 & 0.327 \\
Non-Business Student & 85 & 17.35 & $10-23$ & 2.529 & 0.274 \\
SME Business Group & 84 & 17.23 & $9-24$ & 3.250 & 0.355 \\
$\quad$ Grand mean or mean & 254 & 17.43 & - & 2.942 & 0.185 \\
\hline
\end{tabular}

Table 4

Model ANOVA: Independent CEI

\begin{tabular}{lccccc}
\hline \multicolumn{7}{c}{ Carland Entrepreneurship Index Compared in Groups } \\
\hline Source & $\boldsymbol{S S}$ & $\boldsymbol{d f}$ & $\boldsymbol{M S}$ & $\boldsymbol{F}$ & $\boldsymbol{p}$ \\
\hline Respondent Group & 11.025 & 2 & 5.512 & 0.635 & 0.531 \\
Error & 2179.338 & 251 & 8.683 & & \\
\hline
\end{tabular}

The Carland Entrepreneurship Index (CEI) is an index that measures the entrepreneurial. Instruments concerning the CEI were developed and tested for their validity and reliability by Carland et al. (1993). The instrument consists of 33 question items and can be completed in minutes. Each question item contains two questions and the respondent must choose one of the two questions. One statement will be scored one and the other zero. So the score will have a range from zero to 33 where a score close to zero indicates a low entrepreneurial spirit and a score close to 33 indicates a high entrepreneurial spirit.

Carland et al. (1993) developed the instrument to gain insights into the strengths of the main characteristics of entrepreneurs that have long been predicted by many researchers. They conclude that entrepreneurship is a function of four elements, namely: personality, innovation, risk-taking, and strategy posture. In addition, CEI is designed to identify strengths over one's entrepreneurial spirit, rather than as an attempt to identify entrepreneurs (Ciptono, 1994). Entrepreneurial drive can explain the differences in behavior that lead to the entrepreneurial spirit in a person.

As described in the descriptive statistics section, the average CEI score for the whole group is almost the same as the 17.72 scored by the business students' group, or the 17.35 by the non-business students' group, and the 17.23 scored by the business owners/ workers' group. After a statistical test, using the ANOVA test apparatus, there was no significant difference in the CEI scores between the three groups $[p=0.635>0.05]$. So the answer to the second question has been answered. That there is no systematic difference in the entrepreneurial spirit between business students, non-business students, and business owners/workers.

Still, on the CEI scores obtained for the three groups, in the business owners' group, the number of respondents who scored high CEI (20-25) scores was greater than the other two groups of business students and non-business students. Although the amount of the difference in the scores is not significant, it is interesting to discuss. With the same sample size for each group, it turns out that the greatest numbers of respondents who can be said to have a high entrepreneural drive are in the business owners group, all of whom are involved in business every day, unlike the members of the other two groups. It would be more interesting if the number of samples is further enlarged, where the proportion of business owners, who should have a high CEI score compared to other groups, will also be enlarged. Thus someone who has a high CEI score has the potential to become someone who is able to run a business well.

The Carland et al. (1993) study found that entrepreneurial drives empirically can see the difference between entrepreneurs managing largegrowth firms and small-growth firms. The findings may explain why CEI scores from business groups can be said to be not very high, or in other words, their score is the same as the other two groups, namely groups of business students and non-business students.

As described in the descriptive statistics section, it is known that the majority of respondents from business groups (86\%) are business owners running small businesses or companies. The age of the respondents in that group is in the range of 19 to 22 years, which indicates they are still young and there is the possibility that their business is still corn-aged, despite the possibility that their business is a family business that has been running for a long time. It is a problem with this research, that in the demographic section there should be information on how long the respondents have run their businesses, so that information can help explain the research results. Even so, more research is required to find this information. 
Carland et al. (1993) conducted a study of 147 US business students and found that their temperament was very significantly associated with the entrepreneurial index. A similar study was conducted by Ciptono (1994), using a sample of 70 Indonesian students studying in the USA; he found that individual temperament or motivation had little influence on the determination of entrepreneurial tendencies. Based on the research results of Carland et al. (1993) we can conclude that entrepreneurship tends to be part of a person's own potential, and will be more developed if it interacts with the environment. But apparently it is still not consistent.

Armstrong and Hird (2009) and Purusottama (2019) conducted a similar study. Armstrong and Hird (2009) try to find empirical evidence regarding whether cognitive and entrepreneurial drives are important to identify individuals who have the potential to be successful entrepreneurs. The results show that entrerpeneurs tend to have a more intuitive and less analytical cognitive style than non-entrepreneurs. The more intuitive an entrepreneur is, the higher his entrepreneurial. Hereafter, Purusottama (2019) found that there are two things that have a significant role in entrepreneurial intention among student, which are attitude and perceived control behavior.

This study does not try to find out the cognitive style of its respondents. There is the possibility that the respondents in the group of non-business students may have an intuitive cognitive style similar to the respondents in the group of business students. Or it could be otherwise, that the cognitive style of the respondents who are in the group of business students tends to be analytical, similar to the respondents who are in the group of non-business students.

Kalla (2011) said that another factor that can influence entrepreneurship is the level of education. Education is an attempt to foster self-identity, in accordance with the values that exist in society and culture. Education is essentially a human effort to vindicate life. Education deals with general knowledge and understanding of the entire work environment, including knowledge of entrepreneurial characteristics. The respondents in this study, irrespective of which group they were in, had the same level of education as the first strata. The difference was if they undertook any courses related to business or not. Perhaps the level of education, regardless of the type of courses acquired, will determine the magnitude of one's entrepreneurial spirit. In a similar way, Coddington (2015) and Purusottama (2019) also stated that the entrepreneurial spirit is also relied on an understanding of each individual to their environment. Various entrepreneurial images obtain- ed by each individual in their environment, give a bigger strength to their willingnes and intention to become entrepreneurs.

This study found no empirical evidence of differences in the entrepreneurial between groups of business students, non-business students, and business owners. Based on the exposures described above, this study concludes that entrepreneurial is inherent as a talent or trait since birth. A business education is not (or may not be) able to influence the magnitude or entrepreneurship of a person. A lot of evidence shows that a person who does not get a business education, whether formal or nonformal (the school is not high), can still be a successful entrepreneur, maybe because they do have an entrepreneurial spirit.

Related to that, Suwarni (2008) examined the impact of entrepreneurship courses on entrepreneurship's spirit in accounting students. These research subjects were good students who either were given entrepreneurship lecture material, or not. The findings of this study indicate that there is no entrepreneurial spirit differentiation between groups of students who have obtained entrepreneurship lecture materials or not.

\section{Conclusions and Limitations}

This study found no empirical evidence of differences in entrepreneurnial in three groups, ie a group of business students, non-business students, and business owners. Another thing that can be concluded, based on this research, is that entrepreneurial is a talent or trait some people are born with. Business education is not (or has not) been able to be something that can trigger one's entrepreneurial.

However, it does not mean business education will not influence one's entrepreneurial. There needs to be a more in-depth assessment of the business education curriculum in Indonesia. The Indonesian government needs to review its education program. As stated also by Jufri and Wirawan (2018) in their research that the spirit of entrepreneurship can be developed by considering local values, for the example through traditional games even starting from childhood education. Moreover, as studied and found by Rina (2019) there are satisfactory results if the curriculum involve students in activities that are linked to leadership skills. That is important because through leadership activities, the internalization of entrepreneurial character can be developed.

Carland entrepreneurship index may indeed be able to measure how much someone possesses an entrepreneurial spirit, but their cognitive style may be more useful in identifying individuals who have the potential to become successful entrepreneurs. 
Another limitation of this research is not asking about how long the entrepreneur respondents run their businesses, thus losing the opportunity for an additional explanation of the results of this study. The analysis of the difference in entrepreneurnial spirit among fellow business students with different specific majoring (or concentration) seems to be interesting, considering the proportion of given business courses may be different, for example marketing management students will certainly receive more subjects that relate to business than other business students like accounting students, financial management students, economics students, etc. For the next research, can also investigate the consequences of entrepreneurial spirit the intention to start the business (Widayat \& Ni'matuzahroh, 2017) especially for students but for differ group characteristics (class consentration, gender, personality traits, age, etc.).

\section{References}

Alexandrova, M. (2004), Entrepreneurship in a transition economy: The impact of environment on entrepreneurial orientation. Problem and Perspective in Management, 2(2), 140-148.

Alma, B. (2005). Kewirausahaan. Bandung: Alfabeta.

Armstrong, S. J., \& Hird, A. (2009). Cognitive style and entrepreneurial drive of new and mature business owner-managers. Journal Business Psychology, 24, 419-430.

Barreira, J. (2010). Early thinking and emergence of entrepreneurship. In B. Urban, Frontiers in Entrepreneurship (pp. 1-32). Berlin, Heidelberg: Springer.

Bohušová, H., \& Blašková, V. (2012). In What ways are countries which have already adopted ifrs for smes different? Acta Universitatis Agriculturae et Silviculturae Mendelianae Brunensis, LX(2), 37-44.

Burch, J. G. (1986). Profiling the entrepreneur. Business Horizons, 29(5), 13-16.

Carland, J. A., Carland J. W., \& Higgs, R. C. (1993). Portraits of potential entrepreneurs: An empirical investigation. Journal of Business and Entrepreneurship, 5(1), 59-66.

Ciptono, W. S. (1994). The entrepreneurship style of students: An empirical investigation of Indonesia students. Kelola, 6(III), 105-114.

Coddington, K. (2015). The entrepreneurial spirit: Exxon Valdez and nature tourism development in Seward, Alaska. Tourism Geographies, 17(3), 482-497.

Dollinger, M. J. (1995). Entrepreneurship: Strategies and resources. Homewood, IL: Austen Press; Burr Ridge, Ill.: Irwin.
Doyle, W., Fisher, R., \& Young, J. D. (2002). Entrepreneurs: Relationships between cognitive style and enrepreneurial drive. Journal of Small Business and Entrepreneurship, 16(2), 2-20.

Drucker, P. F. (1994). Innovation and entrepreneurship: Practices and principles. Jakarta: Gelora Aksara Pratama.

Hisrich, R. D., \& Peters, M. P. (1995). Entrepreneurship. Chicago: Richard D. Irwin.

Idrus, M. S. (1999). Strategi pengembangan kewirausahaan (entrepreneruship) dan peranan perguruan tinggi dalam rangka membangun keunggulan bersaing (competitive advantage) bangsa Indonesia dalam milenium ketiga. Pidato Pengukuhan Jabatan Guru Besar Universitas Brawijaya.

Indarti, N., \& Kristiansen, S. (2003). Determinants of entrepreneurial intention: The case of Norwegian students. Gadjah Mada International Journal of Business, 5(1), 79-95.

Jufri, M., \& Wirawan, H. (2018). Internalizing the spirit of entrepreneurship in early childhood education through traditional games. Education + Training, 60(7/8), 767-780.

Kalla, M. J. (2011). Kemajuan bangsa, pendidikan dan kewirausahaan. Pidato Ilmiah Penerimaan Gelar Doktor Kehormatan. Universitas Pendidikan Indonesia Bandung.

Kartasasmita, Y. (1994). Buku pegangan kewirausahaan. Bandung: UPT-Penerbitan IKOPIN.

Longenecker, J. G., Moore, C. W., \& Petty, J. W. (2000). Small business management: An entrepreneurial emphasis. $11^{\text {th }}$ Edition. Cincinnati: South-Western Collage Publishing Co.

Lumpkin, G. T., \& Dess, G. G. (1996). Clarifying the entrepreneurial orientation construct and lingking it to performance. Academy of Management Review, 21(1), 135-172.

Mahrinasari. (2003). Faktor-faktor apakah yang mempengaruhi kualitas jiwa kewirausahaan pelaku usaha kecil, khususnya pada sub-sektor industri pengolahan makanan dan minuman di Kota Bandar Lampung. Jurnal Ekonomi, 1(2), 23-30.

Masu, E., \& Goswani, U. (1999). Factors for success in small manufacturing firms. Journal of Small Business Management, 26(1), 61-68.

Mitchelmore, S., \& Rowley, J. (2010). Entrepreneurial competencies: A literature review and development agenda. International Journal of Entrepreneurial Behavior and Research, 16(2), 92-111.

Mueller, S. L., \& Thomas, A. S. (2000). Culture and entrepreneurial potential: A nine country study of locus of control and innovativeness. Journal of Business Venturing, 16(1), 51-75. 
Pekerti, A. (1992), Mitos dan teori dalam pengembangan wirausaha, seri forum, no. 5. kuliah dan monografi: Manajemen koperasi dan pengembangannya. Jakarta: South Asian Forum for Development Alternative.

Purusottama, A. (2019). Revisiting students' entrepreneurial intention in Indonesia: A theory of planned behavior approach. Jurnal Manajemen dan Kewirausahaan, 21(1), 64-73.

Rina, L. (2019). Student leadership in school: Internalization of entrepreneurial competence and character. Jurnal Manajemen dan Kewirausahaan, 2l(1), 1-8.

Setyorini, M., \& Sunaryo, S. (2004). Pengaruh faktor personal dan lingkungan terhadap keinginan berwirausaha (Penelitian pada mahasiswa sebuah perguruan tinggi di Surakarta). Buletin Ekonomi, 2(2), 96-105.
Suryana. (2006). Kewirausahaan: Pedoman praktis kiat dan proses menuju sukses. Jakarta: Salemba Empat.

Suwarni, E. (2008). Pengaruh pemberian materi kuliah kewirausahaan terhadap jiwa kewirausahaan pada mahasiswa akuntansi. Journal Accounting Business \& Management, 15(1), 13-27.

Widayat \& Ni'matuzahroh. (2017). Entrepreneurial attitude and student's business start-up intention: A partial least square modeling. Jurnal Manajemen dan Kewirausahaan, 19(1), 46-53.

Wiratmo, M. (1996). Pengantar kewiraswastaan: Kerangka dasar memasuki dunia bisnis. Jogjakarta: BPFE.

Zeffane, R. (2014). Does collectivism necessarily negate the spirit of entrepreneurship? International Journal of Entrepreneurial Behavior \& Research, 20(3), 278-296. 